depletion on a scale comparable to that of wildlife. In 1893 the Superintendent of the North West Mounted Police in Maple Creek reported: "the supply (of timber) in the Hills is rapidly getting short, owing to the encroachments of settlers and destruction by fire"...

One of the first forest reserves established under the Dominion Forest Reserves Act of 1906 was the Cypress Hills Forest Reserve, which included a portion of the Hills forest resource ...

In 1930 the control of natural resources in Alberta and Saskatchewan was transferred to the provinces. In Alberta, the Cypress Hills Forest Reserve, initially managed under the Forest Reserves Act, eventually became today's Cypress Hills Provincial Park under the Provincial Parks and Protected Areas Act. In Saskatchewan, the Reserve, which comprised three blocks, became the Cypress Hills Provincial Forest (west block) and the Cypress Hills Provincial Park (centre block) under the Forest Act and the Provincial Parks and Protected Areas Act respectively. The east block was eventually designated a provincial community pasture.

Today ... both the Alberta and Saskatchewan governments are evaluating new Master Plan studies aimed at reassessing multiple-use priorities and optimizing park uses.

\title{
FIRST RECORDS OF ROCKY MOUNTAIN JUNIPER IN SASKATCHEWAN
}

V. L. HARMS, Fraser Herbarium, University of Saskatchewan, Saskatoon and DALE G. HJERTAAS, Ducks Unlimited, 5-1615 11th Ave., Regina, Sask.

During the last year two articles have appeared in the Blue Jay which have reported eastward range exten. sions of the Rocky Mountain Juniper (Juniperus scopulorum Sarg.) in Alberta. This erect shrub or small tree had long been known from the Waterton Lakes, Banff, and Crowsnest Pass areas of Alberta and most probably is present in a more or less continuous distribution between those Rocky Mountain sites. ${ }^{6}{ }^{5}$ Recently single isolated "trees" of Rocky Mountain Juniper were reported from two more eastern Alberta localities, the first at Glenwood near Cardston (Sec. 34, T 4, R 27 W 4th) and the second in the Oldman River valley just north of Lethbridge. ${ }^{4}$ Even more recently
(1975) and significantly another single isolated "tree" of this species was found near the southeastern corner of Alberta (SE 1/4 Sec. 5, T 1, R4 W 4 th) ${ }^{7}$

In the present article, we would like to report the recent discovery of naturally growing Rocky Mountain Junipers at three widely separated localities in southern Saskatchewan. The first finding of this species in Saskatchewan was by a group of University of Saskatchewan Biology students, including Marie Jasieniuk Wayne Renaud and K. J. Finley, who on May 25, 1975, discovered a tree a a location "somewhere southwest of Killdeer". These students, and in par. ticular, Marie Jasieniuk, recognizec 


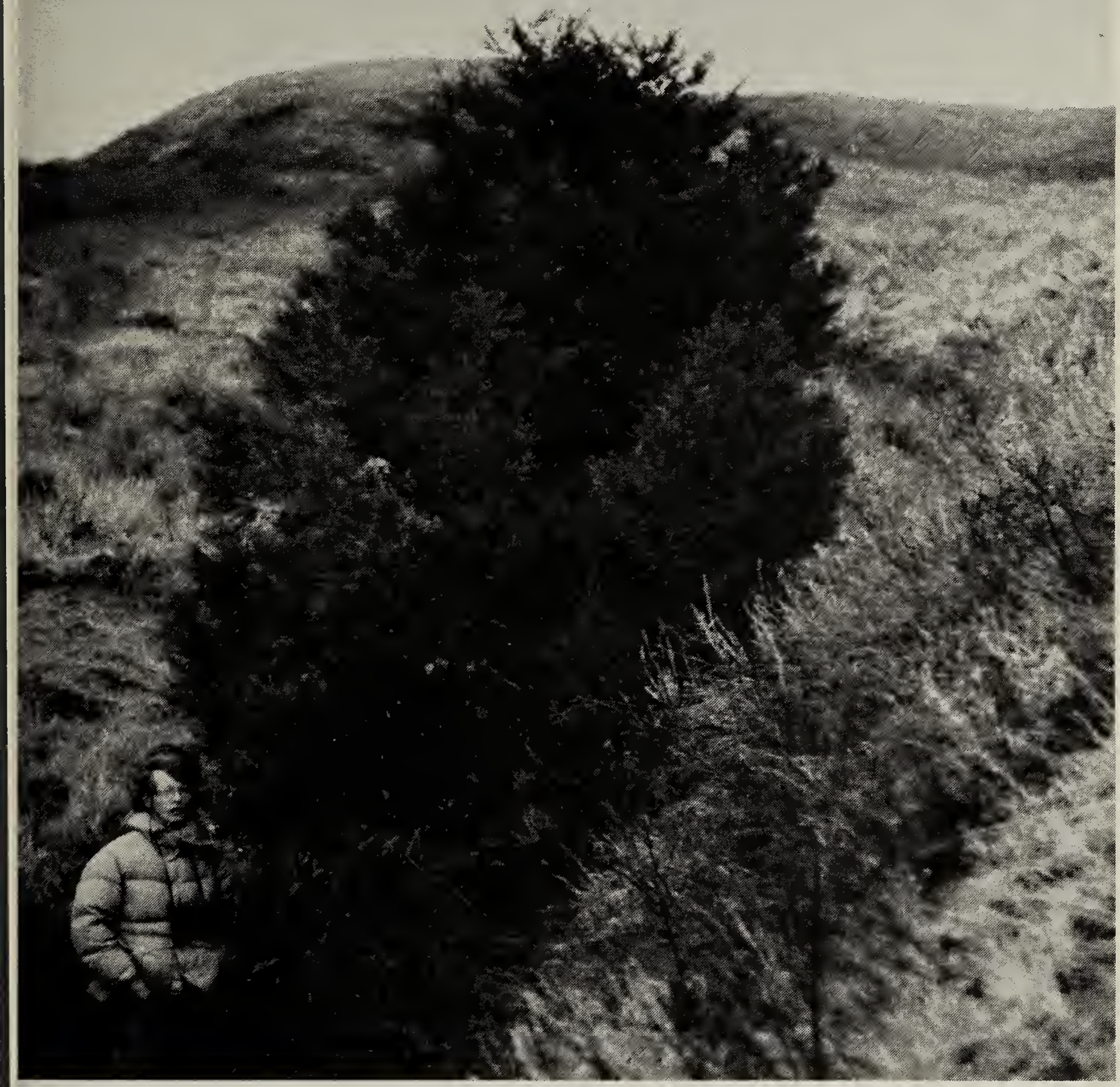

Figure 1. Rocky Mountain Juniper near Killdeer, Saskatchewan.

Frank Dowling

the tree as something unusual for Saskatchewan and subsequently brought one of us (V.L.H.) a description of it, including its height (about 3 $m$ or $10^{\prime}$ ) and habit (a single erect trunk), as well as a small twig fragment (which unfortunately was later misplaced), allowing for its positive identification as the Rocky Mountain Juniper.

This spring, the junior author (D.G.H.) attempted to relocate this Killdeer area site in order to obtain a voucher specimen, photograph, and full description to better substantiate the record. On April 17, 1976, a single isolated "tree" of Rocky Mountain
Juniper (almost certainly the same one found in 1975) was located in the general Wood Mountain area about 7 miles west and 3-1/2 miles south of Killdeer (N1/2 Sec. 19 or S1/2 Sec. 30, T 1, R 4, W 3rd). The "tree" was about 3 metres $\left(10^{\prime}\right)$ high with a single erect trunk about $12 \mathrm{~cm}$. $\left(5^{\prime \prime}\right)$ in diameter at the base (Fig. 1). It was growing near the top of a steep, north-facing slope of a dry channel at the bottom of a canyon draining westward into Morgan Creek.

The immediately associated vegetation consisted mainly of the shrubs, Hoary Sagebrush (Artemisia cana) and Western Snowberry (Sym- 


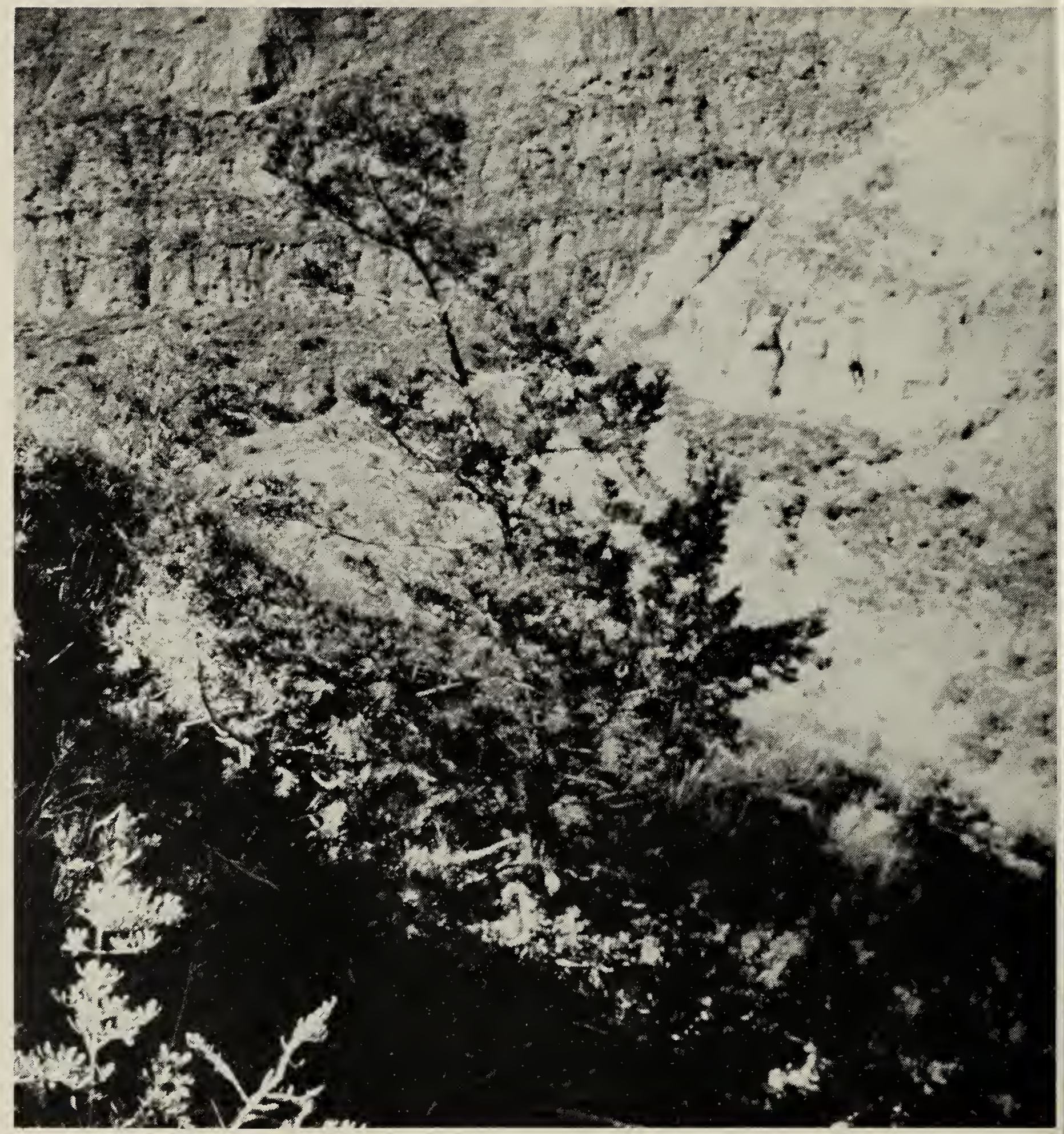

Figure 2. Rocky Mountain Juniper in Big Muddy Badlands.

D. G. Hjertaas.

phoricarpos occidentalis Hook), with Spear-grass (Stipa comata) appearing to represent the most common graminoid herb. However, it was too early in the spring season to recognize most herbaceous species. A voucher specimen of this "tree" has been filed in the Graser Herbarium of the University of Saskatchewan as D. G. Hjertaas, 17 April 1976 (SASK. No. 56850).

Last autumn, on November 5, 1975 , the junior author (D.G.H.) discovered a small population of six "trees" of this species in the Big Muddy Badlands about 11 miles east of Big Beaver,
Saskatchewan, 1/2 mile southeast of Big Muddy Lake, on the east side of a southward extending bay (NW 1/4 Sec. 14, T 2, R 22, W 2nd). The "trees" were about $2-1 / 2$ metres ( $\left.8^{\prime}\right)$ high and had single erect trunks about $10 \mathrm{~cm}$. (4') in diameter (Fig. 2). These Rocky Mountain Juniper "trees" were growing in a fairly close clump on a rather steep, open, clayey, north-facing slope of a canyon in the bottom of a large ravine leading into Big Muddy Lake; they were about 100 feet above the gully bottom and about 150 feet below the canyon lip. The most con- 
spicuous associated plant species were the shrubs, Western Snowberry, Hoary Sagebrush and Creeping Juniper (Juniperus horizontalis Moench.); however, it was too late in the season (winter conditions existed) to allow for the recognition of all associated, especially herbaceous, plant species. A voucher specimen has been filed in the Fraser Herbarium of the University of Saskatchewan as D. G. Hjertaas, 5 November 1975 (SASK No. 56760).

This locality was revisited by the junior author (D.G.H.) this spring on May 28, 1976. In addition to the original colony of six trees located at the first site visited, two additional sites of Rocky Mountain Juniper were discovered in nearby areas, but all still within the same quarter section given above. At the second site, three trees, 2 - 2-1/2 metres (7-8') high, with basal trunk diameters of $7-1 / 2-10 \mathrm{~cm}$. (3$4^{\prime \prime}$, we found growing on the opposite, south-facing, steep slope of the same canyon as Site 1, about 20 feet below the canyon rim. They were on largely bare ground but associated with clumps of Hoary Sagebrush, Low Juniper (Juniperus communis), Creeping Juniper, Wheatgrass (Agropyron sp.), Prickly Pear Cactus (Opuntia polycantha), Western Snowberry and Woods Rose (Roas woodsii).

A third site, consisting of a single tree (Fig. 2) about $2-1 / 2$ metres ( $\left.8^{\prime}\right)$ tall and about $10 \mathrm{~cm}$. (4") in diameter, was located in another canyon just over the ridge north of the canyon which contained sites 1 and 2. The tree was growing on a steep east-facing slope of a large gully cutting into the north-facing canyon wall, about a third of the way down the canyon side. The associated vegetation included predominantly both Creeping and Low Juniper as well as lesser amounts of Western Snowberry, Woods Rose, Wheatgrass and other grasses. A voucher specimen was collected from this tree at Site 3 and is filed in the Fraser Herbarium as D. J. H.jertaas, 28 May 1976 (SASK No. 56762).

Thus the overall Big Muddy Badlands' population of Rocky Moun- tain Juniper consists of at least 10 trees, which is a noteworthy point when we consider that the other recently reported sites at Cardston, Lethbridge, and southeastern Alberta, and at Killdeer, Saskatchewan, each consisted apparently of a single isolated tree.

In addition to these two new localities for Saskatchewan from the Killdeer and Big Muddy Badlands areas, which are both well documented by voucher specimens, photographs and descriptions, there is now an additional good observational report by Wayne Runge (Wildlife Branch, Saskatchewan Department of Tourism and Renewable Resources, Saskatoon) of a "cedar tree", which by the description appears to be the Rocky Mountain Juniper, from the Frenchman River Valley near the United States border (N-1/2 Sec. 4, T 1, R 10, W $3 \mathrm{rd}$ ). This site is within a mile of where the Frenchman River crosses the international boundary and is about 30 air miles southeast of $\mathrm{Val}$ Marie (about 24 miles south of Reliance and 24 miles east of Monchy). The "tree" was about 2 metres $\left(6^{\prime}\right)$ tall with a basal trunk diameter of about $8 \mathrm{~cm}$. $\left(3^{\prime \prime}\right)$. It was growing near the top of a steep east-facing slope of a gully which was about 8 feet deep and 20 feet wide, located on the lower slopes near the river valley floor. Growing in close proximity to it was the Low Juniper. The observer described the leaves of this specimen as being scale-like such as those of the Red Cedar (Juniperus virginiana L.) and Creeping Juniper. Being more familiar with the eastern Red Cedar and not aware of the northwestward limitation of its range or the fact that no tree-sized or erect shrub juniper (or cedar) species with scale-leaves had yet been reported for Saskatchewan, the observer did not obtain a voucher specimen or a photographic record of this "tree". However, it seems likely that this was a Rocky Mountain Juniper.

The Frenchman River site is about 160 miles east of the south-eastern Alberta locality and about 35 miles 
west of the Killdeer site. ${ }^{7}$ The latter is about 75 miles west of the Big Muddy Badlands population of Rocky Mountain Juniper, which is now the easternmost record for Canada. These first records for this species in Saskatchewan extend its known Canadian range about 250 miles eastward from the southeastern Alberta, and over 400 miles east of the Canadian Rocky Mountain sites. However, while certainly significant and representing interesting first reports for the species in Saskatchewan, these range extensions are less spectacular than it might first appear, when the overall known North American, and not just Canadian, distribution of the Rocky Mountain Juniper is considered (see distribution map of Fig. 3). Although the species had not been recorded east of the Rocky Mountains in Canada until 1975, disjunct small colonies or sometimes large populations have been known from numerous localities east of the Rocky Mountains across central and eastern Montana and Wyoming to the western Dakotas." $*$ Of particular interest to us is the species' known occurrence at various sites along the valley breaks of the Missouri River and its tributaries in Montana and western North Dakota, where it occurs most commonly on relatively steep coulee or ravine slopes. It is especially abundant in the Little Missouri River Badlands in western North Dakota, a locality which is even farther east than our presently recorded Big Muddy Badlands' population in Saskatchewan. ${ }^{8}$

On the North American distribution map of the Rocky Mountain Juniper (Fig. 3), our new Saskatchewan locality records, as well as those reported by Kuijt and Trofymow and Smith and Wallis for Alberta east of the Rocky Mountains, are indicated by an "X" ${ }^{4} 7$ The Cardston and Lethbridge sites are both located in the South Saskatchewan River drainage system, but are within 30 and 75 miles, respectively, of previously known sites for the species in the Rocky Mountains. The Big Muddy Badlands, Killdeer and Frenchman River Valley sites in Saskatchewan, and the southeastern Alberta site are located in the Big Muddy Creek, Poplar River, Frenchman River, and Milk River watersheds, respectively, all of these representing northward-extending tributaries of the Missouri River. Furthermore, all of these sites are less than 100 miles distant, and sometimes much less, from previously recorded localities for the Rocky Mountain Juniper along the Missouri River valley drainage in northeastern Montana.

In both of the recent new reports of the Rocky Mountain Juniper at sites in Alberta east of the Rocky Mountains, the authors strongly subscribed to the theory of long-distance dispersal as the explanation for these isolated distributions. ${ }^{4} 7$ Usually this is indeed the most logical interpretation for such occurrences, especially when one finds only single isolated individuals located at a considerable distance from the previously known range of a species. We also believe that Smith and Wallis are quite correct in pointing southward rather than westward for the most probable seed source of such possible long-range dispersals. ${ }^{7}$ Such long-range dispersal, perhaps by avian transport of juniper "berries" from Missouri River valley populations in northeastern Montana, may well be the best explanation for the origin of our southern Saskatchewan sites of Rocky Mountain Juniper. However, this is not the only interpretation possible. In our opinion, most historical phytogeographers, when observing the overall presentday North American distribution of this species (Fig. 3), would tend to interpret it as a rather good example of a Cordilleran (Rocky Mountain) species which at one time, perhaps in early post-Pleistocene times, probably had a wider and more continuous distribution to the east and probably north (and also to the west, although perhaps at an earlier time), but which has since, likely as a result of changing climates, contracted its range leaving behind disjunct populations in particularly favourable habitats such as in the Black Hills, Little Missouri River Badlands, breaks along the Missouri 


\section{IDENTIFICATION KEY FOR THE NATIVE JUNIPERS (GENUS JUNIPERUS) IN SASKATCHEWAN}

1(a) Leaves whorled, 3 at each node, all being awl-shaped needles rather than scale-like, (5) 7-12(15) $\mathrm{mm}$ (about 1/3-2/3") long, 1-2 mm (<1/8") wide, jointed at the base, with a whitish strip (containing the stomata) on the upper surface, and lacking a glandular dot on the back surface; plants are low widely spreading shrubs, either prostrate or semi-erect, usually less than 1 metre high ... Juniperus communis L. Low Juniper

2(a) Plants low, flat-topped shrubs, often forming circular clumps with the main trunks at least partially erect, 4-10 (15) dm (or 1-1/2-3(5)') high; leaves spine-tipped, 7-12 $\mathrm{mm}$ (1/4-1/2") long, quite divergent, with the whitish strip on the upper surface mostly narrower than half the leaf width; (merging into the next variety) ....J. communis var. depressa Pursh.

2(b) Plants forming close ground mats, entirely prostrate or decumbent, with the main stem as well as branches trailing, or if the main stem somewhat erect, shorter than $3 \mathrm{dm}$ (1') high; leaves abruptly sharp-pointed but not spine-tipped, averaging somewhat shorter, 5-10 mm (mostly $<1 / 3$ ") long, mostly strongly ascending, with the whitish strip on upper surface usually wider than half the leaf width; (merging with the previous variety) . . J. communis var. saxatilis Pallas (=var. montana Ait.)

(b) Leaves opposite, with only 2 at each node, mostly scale-like, less than $3 \mathrm{~mm}$ $\left(1 / 8^{\prime \prime}\right)$ long [except leaves of juvenile shoots which are sometimes awlshaped and longer, but mostly less than $5(7) \mathrm{mm}(<1 / 4$ ') long, but not basally jointed, and lacking a whitish strip on upper surface, usually with a conspicuous elongated glandular dot on the back surface: plants are prostrate shrubs to erect trees.

3(a) Low trailing shrubs with the main stems and branches all prostrate or with only their ends upturned; scale leaves very pungent, abruptly ending in a sharp, short but distinct spine-tip ... Juniperus horizontalis Moench: Creeping Juniper

3(b) Shrubs or small trees, 1-5 (12) metres (3-15') tall, more or less erect with single main trunk; scale leaves less pungent, with tips blunt to rather sharply pointed, but seldom ending in a short spine . . . Juniperus scopulorum Sarg. Rocky Mountain Juniper

and Yellowstone River valleys, and numerous other isolated sites, including possibly those in the southern Saskatchewan badlands. The presence of a population of at least 10 individuals at the Big Muddy Badlands locality, rather than just a single isolated individual, at least suggests the real possibility that these represent a relict population rather than newly established migrants. The species as a whole may yet be tending toward a further contraction of range with the impending extinction of its more peripheral populations such as those in southern Saskatchewan.

However, whatever their actual origin in the province might have been, we would suggest that other sites for the Rocky Mountain Juniper may very well exist in southern Saskatchewan, especially near the United States border in the various areas of badlands between Val Marie and the Missouri Couteau region east of Big Muddy Lake, and also in the southern Cypress Hills region. It should be looked for by botanists and naturalists who may find themselves in these areas of the province, which have, for the most part, been relatively inaccessible to most persons except the ranchers who have utilized the land for grazing.

In its leafy twig and reproductive structures, the Rocky Mountain Juniper is similar to our common 
Creeping Juniper. It differs in its greater height (1-1/2-12 metres), its habit as a more or less erect shrub or small tree with a single main trunk in contrast to the Creeping Juniper which is entirely prostrate with both the main stem and branches trailing along the ground. The Rocky Mountain Juniper's scale-leaves are also less pungent when crushed, and blunt to abruptly sharp-pointed but not as sharply spine-tipped as those of the Creeping Juniper. These two species apparently are quite closely related and purported hybrid types have often been reported where they coexist. ${ }^{3}$ Such intermediate forms, therefore, might possibly also be expected in southern Saskatchewan. They are characterized by a short more or less erect main stem (or trunk), diffusely branched, partially decumbent (i.e., branches spreading but upright towards tips) growth form, seldom reaching more than one metre in height, and have been named $J$. scopulorum var. patens Fassett or $J$. $X$. fassettii, Boivin. ${ }^{3} 1$ These should at least be looked for in southern Saskatchewan.
In the key above, numbers in parentheses are extremes beyond normal range.

'BOIVIN, B. 1967. Flora of the Prairie Provinces, Part I. Provancheria 2. Mem. I'Herb. LouisMarie, Fac. d'Agric., Univ. Laval, Quebec City, Que.: pp. 37-38

${ }^{2}$ HARMS, V. L. 1973. Native conifers of Saskatchewan. Blue Jay 31(4):210-214.

"HITCHCOCK, C. L., A. CRONQUIST, and M. OWNBEY. 1969. Vascular plants of the Pacific Northwest. Part 1: Vascular Cryptogams, Gymnosperms, and Monocotyledons. University of Washington Press, Seattle; pp. 105-109.

${ }^{4}$ KUIJT, J and J. A. TROFYMOW. 1975. Range extensions of two rare Alberta shrubs. Blue Jay 33(2): $96-98$

"LITTLE, E. L. 1971. Atlas of United States trees. Vol. I Conifers and Important Hardwoods. Miscellaneous Publication No. 1146, Forest Service, U.S. Dept. of Agriculture, Washington, D.C. (Maps 30-W and 30-N).

${ }^{6}$ MOSS, E. H. 1959. Flora of Alberta, University of Toronto Press: p. 35.

'SMITH, W. W. and C. A. WALLIS. 1976. Extralimital occurence of Rocky Mountain Juniper in southeastern Alberta. Blue Jay 34(2): 67-68.

"STEVENS, O. A. 1952. Handbook of North Dakota plants. North Dakota Agricultural College, Fargo; p. 45.

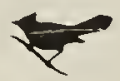

\section{BIRD PREDATION ON THE YELLOW-HEADED SPRUCE SAWFLY, WITH NOTES ON THE LARCH SAWFLY}

WAYNE C. WEBER, Department of Zoology, Mississippi State University, Mississippi State, Mississippi 39762

The yellow-head spruce sawfly (Pikonema alaskensis) is a defoliating insect (Order Hymenoptera, Family Tenthredinidae), found from Alaska and British Columbia to New Brunswick and Maine. Its larvae attack the needles of several species of spruces. ${ }^{2}$ Full-grown larvae are about 0.75 in- ches long, with a chestnut-brown head and a yellowish-green body with darker lengthwise grayish-green stripes (Fig. 1). Infestations rarely occur in closed forest but are usually confined to small ornamental spruces or plantations of young trees. However, they may cause the complete 